\title{
PENGEMBANGAN PROGRAM PEMBELAJARAN FISIKA SMA BERBASIS E-LEARNING DENGAN SCHOOLOGY
}

\author{
Ismu Wahyudi \\ Pendidikan Fisika, FKIP Universitas Lampung, Bandar Lampung \\ email: Kiss_mu18@yahoo.com
}

Diterima: 13 Juni 2017. Disetujui: 16 September 2017. Dipublikasikan: 28 Oktober 2017

\begin{abstract}
Abstrak: E-Learning memberikan solusi alternatif bagi permasalahan pendidikan, dengan fungsi yang dapat disesuaikan dengan kebutuhan, baik sebagai suplemen, komplemen, serta substitusi kegiatan pembelajaran. Proses pembelajaran secara online menggunakan E-Learning dapat melatih peserta didik untuk belajar secara mandiri, sehingga pembelajaran dapat beralih kepada pembelajaran yang berpusat pada siswa. Penelitian ini dilakukan untuk mengembangkan program pembelajaran fisika SMA berbasis elearning dengan schoology di Lampung. Desain penelitian menggunakan model penelitian dan pengembangan, yang dimulai dengan melakukan analisis kebutuhan, identifikasi sumber daya, identifikasi spesifikasi produk, pengembangan produk, uji internal untuk melihat kelayakan produk, uji eksternal untuk melihat kebermanfaatan produk, dan tahap terakhir produksi. Hasil dari uji produk menunjukkan bahwa produk tervalidasi ahli, layak digunakan dan menarik $(3,25)$; mudah digunakan $(3,24)$; dan bermanfaat $(3,31)$. Produk teruji efektif digunakan dalam pembelajaran dengan persentase mencapai $88,82 \%$.
\end{abstract}

Kata kunci: blended learning, e-learning, pembelajaran dengan schoology

\section{THE DEVELOPMENT OF PHYSICS LEARNING PROGRAM BASED ON E-LEARNING WITH SCHOOLOGY}

\begin{abstract}
E-learning gives alternative solution for some educational problems, with the function which can adjust as necessary, as a supplement, complement, and substitution teaching-learning. The learning process by online used e-learning can make the students learn will independently so that teaching-learning can change the students centered learning. This research was conducted to develop teaching-learning in physics senior high school, based e-learning on technology in Lampung. The research design used to research and development model started with doing need assessment, identification of resources, identification product specification, product development, internally tested to see validation of product, external tested to see the use of the product, and the last stage production. The result of the tested the product showed that had validated by an expert, proper to used and interested (3,25); easy to use $(3,24)$; and useful $(3,31)$. The product was effectively tested to use in teaching learning with percentage $88,82 \%$.
\end{abstract}

(C) 2017 Pendidikan Fisika, FTK UIN Raden Intan Lampung

Keywords: blended learning, e-learning, learning with schoology

\section{PENDAHULUAN}

Proses pembelajaran yang mampu melibatkan siswa untuk aktif melakukan kegiatan belajar, akan bermakna bagi peserta didik sehingga diharapkan mampu menumbuhkan nilai-nilai yang dibutuhkan siswa dalam menempuh kehidupan. Asyhari (2015) mengungkapkan bahwa Siswa harus dibekali dengan kemampuan untuk belajar sepanjang hayat, belajar dari aneka sumber, belajar bekerja sama, beradaptasi, dan menyelesaikan masalah.
Untuk itu, paradigma pembelajaran harus diubah dan memosisikan siswa sebagai pusat belajar (student centered), di mana siswa belajar mengonstruksi pengetahuannya sendiri berdasarkan fenomena alam yang terjadi di sekitarnya (Jayanti, Romlah, \& Saregar, 2016; Saregar \& Sunarno, 2013).

Berdasarkan hasil prapenelitian beberapa penyebab rendahnya hasil belajar yaitu pemilihan metode dan media pembelajaran yang digunakan oleh guru pada proses pembelajaran sangat 
kurang tepat dan pengelolaan kegiatan pembelajaran yang masih belum dapat membangkitkan motivasi belajar siswa secara optimal (Gumrowi, 2016). Komponen-komponen peningkatan mutu tersebut meliputi; performence guru, penguasaan materi dan kurikulum, penggunaan metode mengajar, pendayagunaan media atau alat dan fasilitas pendidikan, penyelengaraan pembelajaran dan evaluasi, serta pelaksanaan kegiatan kurikuler dan ekstra-kurikuler (Kemendikbud, 2014).

Media pembelajaran adalah segala sesuatu yang dapat digunakan untuk menyalurkan pesan dari pengirim ke penerima sehingga merangsang pikiran, perasaan, perhatian dan minat serta kemauan peserta didik sedemikian rupa sehingga proses belajar terjadi dalam rangka mencapai tujuan pembelajaran secara efektif (Sukiman, 2012).

Membuat sebuah keputusan untuk terus berinovasi dalam pembelajaran merupakan pilihan yang harus dipilih oleh semua pendidik (Asyhari \& Diani, 2017). Untuk itu, guru mengemban tugas penting, yang harus secara terus-menerus berinovasi dalam mengembangkan media pembelajaran. Inovasi dalam pengembangan media pembelajaran pada masa kemajuan teknologi informasi dan komunikasi secara nyata mendorong lahirnya konsep dan mekanisme pembelajaran berbasis TIK. Konsep yang kemudian dikenal sebagai e-learning ini telah mengubah cara belajar mengajar tradisional lewat tatap muka diruang kelas menjadi pembelajaran berbasis online. Tentu kehadiran e-Learning menjanjikan harapan baru sebagai solusi alternatif bagi permasalahan pendidikan dan pembelajaran. Implementasinya, $e$ learning dapat disesuikan fungsinya dengan kebutuhan, dapat sebagai suplemen, komplemen, serta sebagai substitusi kegiatan pembelajaran di kelas.

Indonesia berada di peringkat kedua setelah Filipina dalam hal pesatnya pertumbuhan pengguna internet di dunia. Berdasarkan laporan Simon Kemp dalam Southeast Asia Digital in 2015, hingga November 2015 pengguna internet telah mencapai 88,1 juta orang atau sekitar 34 $\%$ dari total jumlah penduduk Indonesia (Irwandani, 2016). Survei menunjukkan bahwa akses internet dapat meningkatkan integritas murid dalam proses pembelajaran (Suana, Maharta, Nyeneng, \& Wahyuni, 2017). Adanya teknologi yang terjadi pada saat ini telah membuka jalan bagi para pendidik dan juga teknolog pendidikan untuk mengkaji ulang masalah-masalah yang timbul dalam bidang pendidikan yang ada pada saat ini (Yuberti, 2015). Setiawan, et al. (2014) mengungkapkan bahwa melalui dukungan perkembangan teknologi informasi dan telekomunikasi serta tuntutan kompetisi global, e-learning dirasakan tidak sekedar media alternatif dalam melaksanakan pembelajaran, akan tapi e-learning telah diposisikan sebagai tools untuk mencapai kompetensi kompetitif global.

Salah satu fasilitas teknologi yang dapat dimanfaatkan untuk pembelajaran yaitu electronic learning atau e-learning. $e$ learning merupakan media pembelajaran yang digunakan untuk menyampaikan bahan ajar kepada siswa dengan memanfaatkan teknologi informasi dan komunikasi. Siswa dapat belajar mandiri dengan penggunaan e-learning sebagai media pembelajaran, sehingga akitivitas siswa menjadi pusat dalam pembelajaran. Pembelajaran dengan menggunakan $e$ Learning menuntut siswa untuk lebih mandiri dalam belajar, dengan demikian pembelajaran dengan e-learning dapat meningkatkan aktivitas siswa. (Purwaningsih, Rosidin, \& Wahyudi, 2014) Sistem e-learning semakin berkembang dan telah diimplementasikan di berbagai institusi pendidikan di dunia. Basori dalam Chidayati, dkk. (2017) mengungkapkan bahwa di Amerika Serikat, e-Learning telah digunakan hampir $90 \%$ pada setiap tingkat satuan 
pendidikan yang memiliki lebih dari 10.000 siswa. Berdasarkan manfaat dan kemudahan e-learning, maka munculah berbagai model pengembangan $e$ learning. Mulaidari yang hanya sekadar berbasis power point di kelas, menujuk esistem Learning Management System (LMS). Wijayanti (2017) mengungkapkan bahwa terdapat beberapa jenis LMS yang dapat dimanfaatkan dalam proses pembelajaran diantaranya adalah Schoology, Learnboos, Edmodo, Moodle dan lainlain. Diantara yang lain LMS schoology salah satu situs yang mampu menggabungkan jejaring sosial dan LMS, berbentuk web sosial yang menawarkan pembelajaran sama seperti di dalam kelas secara gratis dan media sosial.

Menurut Horton dalam Ramadhani (2012) e-learning adalah segala pemanfaatan atau penggunaan teknologi internet dan web untuk menciptakan pengalaman belajar. e-learning dapat dipandang sebagai suatu pendekatan yang inovatif untuk dijadikan sebuah desain media penyampaian yang baik, terpusat pada pengguna, interaktif dan sebagai lingkungan belajar yang terbuka, fleksibel dan ditributif. Banyak manfaat e-learning dan fasilitas yang tersedia pada LMS yang dapat mendukung proses pembelajaran, namun hanya sedikit guru yang dapat memanfaatkannya dalam mendukung pembelajaran di kelas.

Pembelajaran dengan e-learning dapat membimbing peserta didik untuk belajar secara mandiri sehingga pembelajaran dapat beralih dari pembelajaran yang berorientasipada guru (teacher centered), menjadi pembelajaran yang berorientasi pada siswa (student centered). Kurniawan (2014) mengungkapkan bahwa pembelajaran dengan berbantuan website dapat menjadikan pembelajaran tersebut berpusat pada siswa. Siswa secara mandiri bertanggung jawab untuk pembelajarannya. Pembelajaran dengan e-learning akan menjadikan siswa aktif memainkan peranan dalam pembelajarannya. Siswa akan berusaha dan berinisiatif dalam merancanakan dan mencari materi secara mandiri. Sehingga dengan menggunakan e-learning dapat memperkaya nilai belajar secara konvensional dan memperkuat model belajar konvensional melalui pengayaan konten dan pengembangan teknologi pendidikan.

E-learning menurut Oetomo dalam Darmawan (2014) merupakan suatu konsep dalam upaya mengintegrasikan proses pembelajaran tradisional (traditional learning), pembelajaran jarak jauh (distance learning), dan pembelajaran yang memadukan berbagai model pembelajaran (blanded learning), yang mengkombinasikan berbagai model pembelajaran yang ditujukan guna mengoptimalkan proses dan layanan pembelajaran baik jauh, tradisional, bermedia, bahkan berbasis komputer. Siswa yang belajar dapat memanfaatkan fasilitas bahan ajar online, kemudian dicetak dan download serta dipelajari secara klasikal baik dikelas maupun diluar kelas, setelah itu mereka diskusi dengan bantuan media cetak, elektronik, maupun online.

Blended learning menurut Harding dan Wood dalam Pertiwi, et al., (2014) pada dasarnya merupakan pengembangan lebih lanjut dari metode e-learning, yaitu penggabungan pembelajaran secara tatap muka dan secara virtual. Blended learning merupakan pendekatan pembelajaran yang mengintegrasikan pembelajaran tradisonal tatap muka dan pembelajaran jarak jauh yang menggunakan sumber belajar online dan beragam pilihan komunikasi yang dapat digunakan guru dan siswa. Pelaksanaan blended learning ini memungkinkan penggunaan sumber belajar online, terutama yang berbasis web, tanpa meninggalkan kegiatan tatap muka, sehingga dengan blended learning, pembelajaran akan menjadi lebih 
bervariasi dan bermakna. Lebih lanjut Rossett, dkk. (2003) menjelaskan bahwa dalam penerapannya blanded learning menggabungkan berbagai sumber secara fisik dan virtual dengan pendekatan seperti tabel 1.

Tabel 1. Pendekatan Blended Learning

\begin{tabular}{cl}
\hline Live face-to-face (formal) \\
\hline 1. & Instructor-led classroom \\
2. & Workshops \\
3. & Coaching/monitoring \\
4. & On-the-job (OTJ) training \\
\hline
\end{tabular}

Live face-to-face (informal)

Virtual collaboration/synchronous

1. Collegial connection

2. Work teams

3. Role modeling

2. E-mentoring

Virtual collaboration/ansynchronous
1. E-mail
2. Online bulletin boards
3. Listservs
4. Online communities

\begin{aligned} & Self-paced learning \\ & \hline 1. Web learning modules \\ & 2. Online resources links \\ & 3. Simulations \\ & 4. Scenarios \\ & 5. Video and audio CD/DVDs \\ & 6. Online self-assessments \\ & 7. Workbooks \\ & \hline\end{aligned}

Performance support

1. Help systems

2. Print job aids

3. Knowledge database

4. Documentation

5. Performance/decision support tools

Schoology merupakan salah satu dari beberapa LMS yang memberikan fasilitas kepada guru dan peserta didik untuk saling berinteraksi dalam lingkungan belajar melalui jejaring sosial online. Menurut Juniarti, et al., (2014) melalui Schoology nantinya peserta didik

dapat mengunduh materi pelajaran, mengerjakan kuis, ujian, dan mengumpulkan tugas yang diberikan oleh guru. Fatur (2013)mengidentifikasi kelebihan Schoology dibandingkan jenis LMS yang lain, seperti terlihat pada tabel 2 .

Tabel 2. Kelebihan LMS Schoology

\begin{tabular}{|c|c|c|c|}
\hline PERBANDINGAN SISTEM (1) & \multicolumn{2}{|c|}{ Edmodo(2)LearnBoost(3) } & \multirow{2}{*}{$\frac{\text { Schoology(4) }}{\sqrt{ }}$} \\
\hline ARCHITECTURE & $\sqrt{ }$ & $\sqrt{ }$ & \\
\hline Sistem Kepengurusan Pembelajaran (LMS) & $\sqrt{ }$ & $\sqrt{ }$ & $\sqrt{ }$ \\
\hline $100 \%$ Cloud-based & $\sqrt{ }$ & $\sqrt{ }$ & $\sqrt{ }$ \\
\hline Hubungan Sosial & $\sqrt{ }$ & $\sqrt{ }$ & $\sqrt{ }$ \\
\hline ALAT PEMBELAJARAN & $\sqrt{ }$ & $\sqrt{ }$ & $\sqrt{ }$ \\
\hline Pembelajaran Teratur \& Pembelajaran Mandiri & $\mathrm{X}$ & $\sqrt{ }$ & $\sqrt{ }$ \\
\hline Komunitas (Learning Community) & $\sqrt{ }$ & $\sqrt{ }$ & $\sqrt{ }$ \\
\hline Media Komunikasi & $\sqrt{ }$ & $\sqrt{ }$ & $\sqrt{ }$ \\
\hline Micro-Blogging & $\sqrt{ }$ & $\sqrt{ }$ & $\sqrt{ }$ \\
\hline Content Migration \& Imports & $\sqrt{ }$ & $\sqrt{ }$ & $\sqrt{ }$ \\
\hline ALAT KEPENGURUSAN & $\sqrt{ }$ & $\sqrt{ }$ & $\sqrt{ }$ \\
\hline Keabsahan (Autentification - SSO) & $\mathrm{X}$ & $\sqrt{ }$ & $\sqrt{ }$ \\
\hline Pendaftaran Pengguna dan Pendaftaran Kursus & $\sqrt{ }$ & $\sqrt{ }$ & $\sqrt{ }$ \\
\hline Kesesuaian Tema & $\mathrm{X}$ & $\mathrm{X}$ & $\sqrt{ }$ \\
\hline Menentukan Peranan, Kebenaran, dan Setting & $\mathrm{X}$ & $\sqrt{ }$ & $\sqrt{ }$ \\
\hline Menyediakan Google Apps & $\mathrm{X}$ & $\sqrt{ }$ & $\sqrt{ }$ \\
\hline
\end{tabular}


Schoology memungkinkan kolaborasi berbagai data individu, kelompok, dan diskusi kelas sehingga schoology sangat cocok dijadikan sebagai media pembelajaran pendukung menggunakan e-learning (Purwaningsih et al., 2014). Implementasi e-learning dengan schoology dalam pembelajaran fisika akan memberikan kesempatan kepada peserta didik untuk dapat berinteraksi sosial sekaligus belajar. Sehingga, perlu dikembangkan e-learning dengan schoology dalam pembelajaran fisika untuk mengetahui bagaimanakah kemenarikan kebermanfaatan, kemudahgunaan dan keefektifan $e$ learning dengan schoology dalam pembelajaran fisika.

\section{METODE PENELITIAN Prosedur Penelitian}

Penelitian dilakukan dengan menggunakan pendekatan Penelitian dan Pengembangan Pendidikan (Education Research and Development). Borg and Gall dalam Yuberti (2014) menjelaskan bahwa Penelitian dan pengembangan ini berbasiskan pada pengembangan model dimana penemuan-penemuan penelitian digunakan untuk mengembangkan produk dan prosedur baru, yang kemudian secara sistematik dilakukan uji lapangan, evaluasi, dan revisi sampai diperoleh/dicapai produk yang praktis dan efektif. Penelitian dilakukan dengan membatasi sampai tahapan kesembilan dari sepuluh tahapan penelitian pengembangan.

Penelitian dimulai dari tahap pertama melakukan studi pendahuluan, pada tahap ini dilakukan analisis kebutuhan dan identifikasi sumber daya, melalui angket dan observasi lapangan. Tahap kedua merencanakan produk, pada tahap ini melalui hasil studi pendahuluan digunakan untuk membuat perencanaan produk berupa desain hipotetik. Kemudian tahap ketiga mengembangkan produk e-learning dengan Schoology menggunakan pendekatan saintifik dilanjutkan dengan validasi kapada ahli subtansi dan ahli desain. Selanjutnya pada tahap keempat, dilakukan uji satu lawan satu terhadap guru Fisika dan siswa di sekolah, hasil uji dianalisis dengan pendekatan kualitatif deskriptif sehingga diperoleh gambaran mengenai komponen produk yang perlu direvisi atau dimodifikasi pada tahap kelima. Adapun Sembilan tahap tersebut dapat dilihat pada gambar 1 berikut,

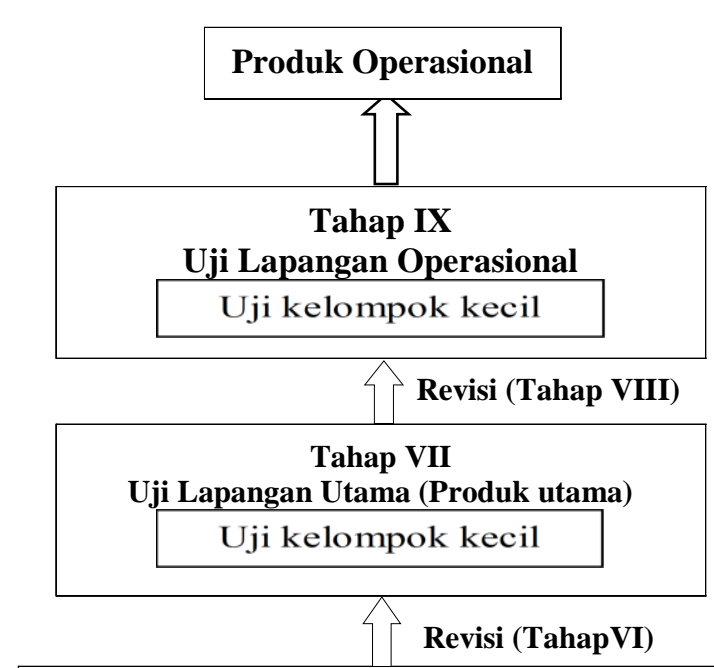

Tahap V

Uji Produk Tahap Awal (Produk awal)

Uji satu lawan satu

Revisi (Tahap IV)

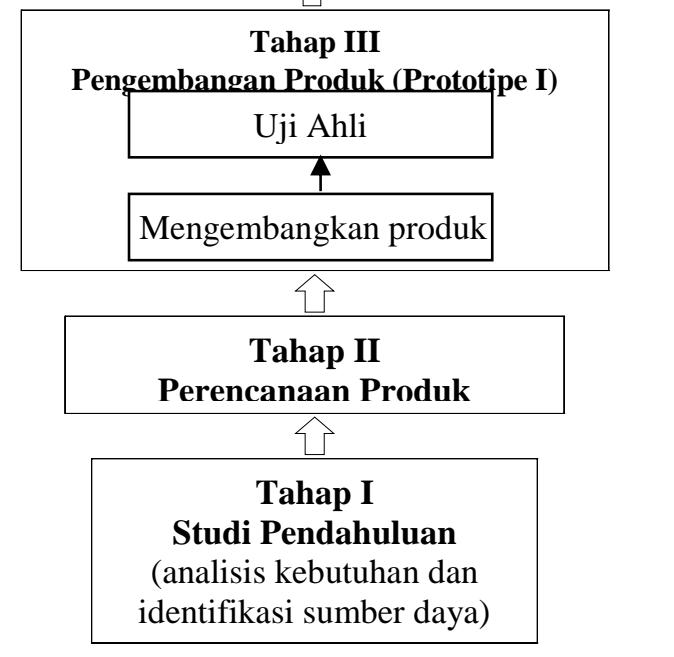

Gambar 1.Pentahapan Pengembangan e-learning 
Selanjutnya berdasar Gambar 1, pada tahap keenam, dilakukan uji coba lapangan utama dengan melakukan uji satu lawan satu dan kelas terbatas, untuk melihat kemenarikan, kebermanfaatan, kemudahgunaan dari produk yang dikembangkan. Tahap ketujuh melakukan revisi produk operasional. Setelah produk operasional dirampungkan, maka dilakukan uji coba lapangan operasional pada tahap kedelapan, untuk melihat keefektifan produk yang dikemabangkan dalam pembelajaran pada enam Sekolah tingkat SMA, masing-masing sekolah 1 kelas eksperimen. Tahap terakhir dari penelitian ini melakukan revisi sehingga menjadi produk operasional yang layak digunakan.

\section{Metode Tes Khusus}

Metode tes khusus digunakan untuk mengetahui tingkat efektifitas produk yang dihasilkan sebagai media pembelajaran. Tahap ini produk digunakan sebagai sumber belajar, pengguna (siswa) diambil sampel penelitian satu kelas siswa dari enam SMA di Lampung, dimana sampel diambil menggunakan teknik randomSampling yaitu SMAN 1 Purbolinggo, SMAN 1 Bandar Lampung, SMA Fransiskus Bandar Lampung, SMA YP Unila, SMAN 1 Natar Lampung Selatan, SMAN 1 Terbanggi Besar.

Memenuhi kebutuhan berdasarkan analisis kebutuhan dan menggunakan desain penelitian One-Shot Case Study. Gambar desain yang digunakan dapat dilihat pada Gambar 2,

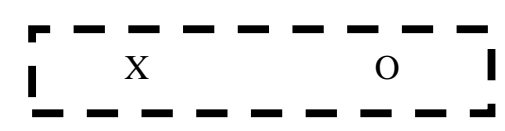

Gambar 2. One-Shot Case Study (Sugiono, 2010: 109)
Keterangan:

$\mathrm{X}=$ Treatment , penggunaan E-Learning

$\mathrm{O}=$ Observasi hasil belajar siswa

\section{HASIL DAN PEMBAHASAN Hasil Penelitian}

Pengembangan program pembelajaran fisika SMA berbasis e-learning dengan menggunakan LMS Schoology sebagai suplemen pembelajaran, dimulai dari studi pendahuluan dengan melakukan analisis kebutuhan dan identifikasi sumber daya, dengan melakukan observasi kondisi nyata di enam sekolah di lampung, dilakukan dengan teknik angket penelitian kepada guru mata pelajaran fisika dan siswa. Berdasarkan analisis ini didapatkan rekomendasi pengembangan produk khusus pada pokok bahasan gerak harmonik sederhana, Hukum gravitasi Newton, Usaha dan Energi, Impuls dan Momentum, Suhu daan Kalor, serta kinematika gerak.

Rekomendasi spesifikasi produk yang dikembangkan adalah e-learning dengan menggunakan LMS yaitu Schoology sebagai suplemen pembelajaran fisika, dengan spesifikasi meliputi materi pokok dan materi pengayaan berupa handout terdiri dari kompetensi inti, kompetensi dasar serta indikator pencapaian kemudian uraian materi yang disesuaikan dengan standar isi kurikulum 2013; video dan simulasi yang berkaitan dengan penerapan materi dalam kehidupan seharihari; contoh soal mengenai materi pokok dan pengayaan tentang materi; diskusi yang berisikan pertanyaan yang berkaitan materi; Latihan soal dan uji keefektifan yang disusun sesuai indikator pencapaiannya.

Pengembangan e-learning berbasis LMS Schoology dengan peneliti sebagai 
instructor atau sebagai guru, dimulai dari mendesain dengan memanfaatkan fitur courses untuk memasukan materi fisika yang dikembangkan. Membuat sebuah folder dengan menggunakan fitur add folder yang terdiri dari petunjuk penggunaan Schoology, handout materi, latihan soal dan uji keefektifan. Handout materi terdiri dari materi pokok dan materi pengayaan yang dilengkapi dengan video pembelajaran dan simulasi, pada handout materi pokok maupun pengayaan dilengkapi dengan contoh soal dengan penyelesaiannya dan juga diskusi.

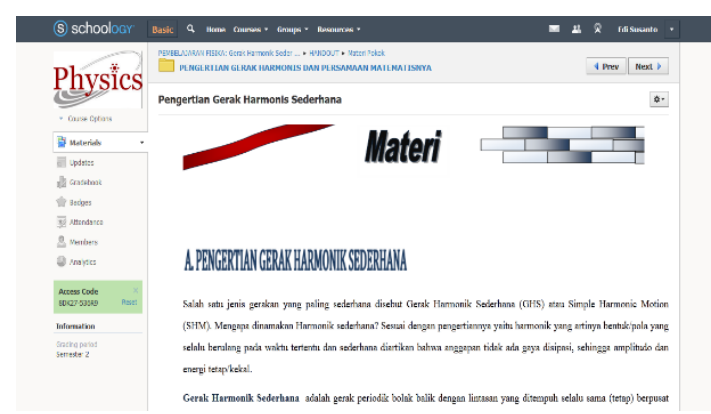

Gambar 3. Tampilan Handoutmateri Gerak Harmonis Sederhana

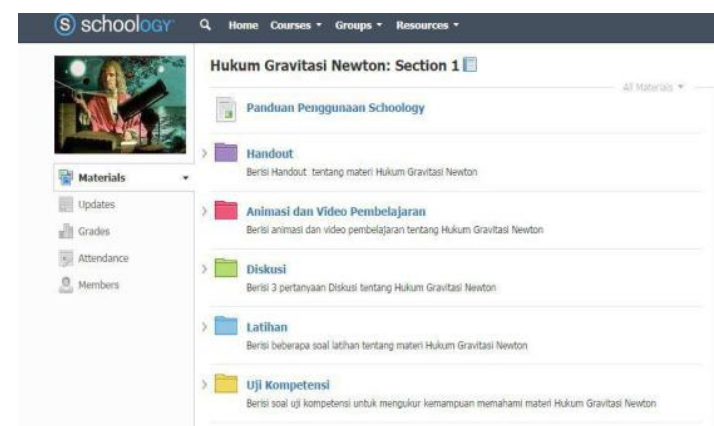

Gambar 4. Tampilan course e-learning Hukum gravitasi Newton

Video dan simulasi pembelajaran ditambahkan melalui fitur add file/link. Soal diskusi dibuat menggunakan fitur discussion, yang dilengkapi dengan gambar dan juga video. Selanjutnya untuk latihan soal dan uji keefktifan dikembangkan dengan fitur test/quiz.
Soal latihan dan uji kompetensi dikembangkan dalam bentuk pilihan jamak yang disertai umpan balik pada setiap jawaban. Statistik nilai hasil latihan dan uji kompetensi dapat dilihat pada fitur gradebook. Hasil pengembangan poduk e-learning pada tahap ini disebut produk awal.

\section{Uji Produk Tahap Awal}

Uji tahap awal ini dilakukan dengan mengujikan produk awal kepada ahli, untuk memvalidasi terhadap desain dan subtansi/materi produk yang dikembangkan. Hasil uji desain produk dan uji ahli materi dapat dilihat pada Tabel 3. Pada uji ahli desain dan subtansi/materi, validator memberikan banyak saran perbaikan atas produk yang dikembangkan.Berdasarkan saran perbaikan dari ahli desain dan materi, dilakukan revisi terhadap produk awal, sehingga didapatkan produk utama.

\section{Uji Lapangan Utama}

Untuk mengetahui kemenarikan, kemudahan, kemanfaatan dan keefektifan produk yang dikembangkan, dilakukan uji satu lawan satu dan uji kelas terbatas kepada pengguna produk. Pada tahap ini dilakukan uji satu lawan satu dilakukan pada 3 siswa pada masing-masing sekolah dan untuk uji lapangan dilakukan pada enam SMA masingmasing satu kelas.

Uji satu lawan satu dilakukan pada enam sekolah, masing-masing sekolah diujikan terhadap 3 orang siswa. Uji ini dimulai dengan memberikan produk kepada siswa untuk digunakan secara mandiri, lalu diberikan angket untuk menyatakan apakah produk sudah menarik, mudah digunakan, dan bermanfaat bagi siswa dalam proses pembelajaran dengan pilihan jawaban "Ya" dan "Tidak" serta dilengkapi dengan saran perbaikan dari siswa sebagai responden. 
Tabel 3.Hasil Uji ahli disain dan uji materi produk

\begin{tabular}{ccccc}
\hline \multirow{2}{*}{ VALIDATOR } & \multicolumn{4}{c}{ HASIL UJI } \\
\cline { 2 - 5 } & Uji Desain & Kualifikasi & Uji Materi & Klasifikasi \\
\hline $\mathrm{V}_{1}$ & 3,75 & Sangat Baik & 4,00 & Sangat Baik \\
\hline $\mathrm{V}_{2}$ & 3,59 & Sangat Baik & 3,73 & Sangat Baik \\
\hline Rerata & 3,59 & Sangat Baik & 3,87 & Sangat Baik \\
\hline
\end{tabular}

Analisis dari respon perbaikan yang diberikan oleh siswa (responden uji), seperti pada Tabel 4. Penilaian kemenarikan, kemudahan, dan kemanfaatan produk diperoleh dari respon siswa terhadap angket respon angket yang diberikan setelah pembelajaran dilakukan, seperti terlihat pada Tabel 5 .

Tabel 4. Komentar, Masukan atau Saran Perbaikan Uji Satu Lawan Satu

\begin{tabular}{ll}
\hline No & Komentar, Masukan atau Saran Perbaikan dari Pengguna \\
\hline 1 & Terdapat kosa kata yang asing sehingga terkadang susah untuk dimengerti. \\
2 & $\begin{array}{l}\text { E-learning menarik untuk dipelajari karena tampilan warna cerah dan gambar yang disajikan } \\
\text { sesuai dengan keseharian, sehingga dapat memperjelas materi pelajaran. }\end{array}$ \\
3 & Penyajian isi pada e-learning lebih baik dibedakan antara materi pokok dan pengayaan . \\
4 & $\begin{array}{l}\text { Pertanyaan-pertanyaan yang terdapat dalam soal latihan hendaknya disajikan lebih jelas lagi } \\
\text { sehingga lebih mudah dipahami. }\end{array}$ \\
6 & $\begin{array}{l}\text { Pada soal latihan dan uji kompetensi hendaknya diberi instruksi agar lebih jelas dan tidak } \\
\text { bingung saat mengerjakan. }\end{array}$ \\
7 & $\begin{array}{l}\text { Penyajian isi pada } e \text {-learning lebih baik dibedakan antarsub materi. } \\
\text { Pertanyaan-pertanyaan yang terdapat dalam soal latihan hendaknya disajikan lebih jelas lagi } \\
\text { sehingga lebih mudah dipahami. }\end{array}$ \\
\hline
\end{tabular}

\section{Uji Lapangan Operasional}

Uji lapangan operasional dilakukan pada 6 SMA di Lampung masing-masing diambil satu kelas sampel secara acak, untuk mengetahui keefektifan produk, produk $e$ learning dengan schoology yang dikembangkan digunakan dalam pembelajaran. Pembelajaran yang dilakukan menggunakan model blended learning, yaitu dengan menggabungkan pembelajaran secara tatap muka (offline) dengan pembelajaran secara virtual class (online) dimanaa guru menugaskan siswa mengakses e-learning dengan schoology di luar kelas, dan mengikuti seluruh aktivitas pembelajaran secara online. Setelah perlakukan pembelajaran diberikan, siswa diberikan posttest sehingga dapat diketahui ketuntasan belajar siswa. Ketuntasan belajar siswa terlihat pada Tabel 6 . 
Tabel 5. Penilaian Siswa terhadap produk e-Learning

\begin{tabular}{|c|c|c|c|c|c|c|}
\hline \multirow{3}{*}{ SEKOLAH } & \multicolumn{6}{|c|}{ ASPEK PENILAIAN } \\
\hline & \multicolumn{2}{|c|}{ Kemenarikan } & \multicolumn{2}{|c|}{ Kemudahan } & \multicolumn{2}{|c|}{ Kebermanfaatan } \\
\hline & Skor & Kategori & Skor & Kategori & Skor & Kategori \\
\hline SMA $X_{1}$ & 3,11 & $\begin{array}{l}\text { Menarik } \\
\text { sangat }\end{array}$ & 3,10 & $\begin{array}{l}\text { Mudah } \\
\text { Sangat }\end{array}$ & 3,12 & $\begin{array}{l}\text { Bermanfaat } \\
\text { Sangat }\end{array}$ \\
\hline SMA X $_{2}$ & 3,73 & $\begin{array}{l}\text { menarik } \\
\text { sangat }\end{array}$ & 4,00 & mudah & 4,00 & \\
\hline SMA $_{3}$ & 3,30 & menarik & 3,23 & Mudah & 3,52 & bermanfaat \\
\hline SMA $_{4}$ & 3,04 & Menarik & 3,09 & Mudah & 3,05 & $\begin{array}{l}\text { Bermanfaat } \\
\text { Sangat }\end{array}$ \\
\hline SMA $_{5}$ & 3,13 & Menarik & 3,15 & Mudah & 3,27 & bermanfaat \\
\hline SMA X $_{6}$ & 3,19 & Menarik & 2,88 & Mudah & 2,91 & $\begin{array}{l}\text { Bermanfaat } \\
\text { Sangat }\end{array}$ \\
\hline Rerata & 3,25 & Menarik & 3,24 & Mudah & 3,31 & bermanfaat \\
\hline
\end{tabular}

Tabel 6. Ketuntasan belajar siswa pada uji keefektifan

\begin{tabular}{|c|c|c|c|c|}
\hline \multirow{2}{*}{$\begin{array}{c}\text { SEKOLAH } \\
\text { (1) }\end{array}$} & \multicolumn{4}{|c|}{ KETUNTASAN BELAJAR SISWA } \\
\hline & $\begin{array}{c}\text { NILAI } \\
(2) \\
\end{array}$ & $\begin{array}{c}\text { PREDIKAT } \\
\text { (3) }\end{array}$ & $\begin{array}{c}\text { FREKUENSI } \\
\text { (4) }\end{array}$ & $\begin{array}{l}\% \\
(5)\end{array}$ \\
\hline \multirow{2}{*}{ 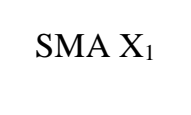 } & $\geq \mathrm{KKM}$ & Tuntas & 36 & 100,00 \\
\hline & $<\mathrm{KKM}$ & Tidak Tuntas & 0 & 0,00 \\
\hline \multirow{2}{*}{ SMA $X_{2}$} & $\geq \mathrm{KKM}$ & Tuntas & 30 & 100,00 \\
\hline & $<\mathrm{KKM}$ & Tidak Tuntas & 0 & 0,00 \\
\hline \multirow{2}{*}{ SMA X 3} & $\geq \mathrm{KKM}$ & Tuntas & 17 & 77,00 \\
\hline & $<\mathrm{KKM}$ & Tidak Tuntas & 5 & 23,00 \\
\hline \multirow{2}{*}{ SMA X $_{4}$} & $\geq \mathrm{KKM}$ & Tuntas & 28 & 82,00 \\
\hline & $<\mathrm{KKM}$ & Tidak Tuntas & 6 & 18,00 \\
\hline \multirow{2}{*}{ SMA $X_{5}$} & $\geq \mathrm{KKM}$ & Tuntas & 20 & 76,92 \\
\hline & $<\mathrm{KKM}$ & Tidak Tuntas & 6 & 23,08 \\
\hline \multirow{2}{*}{ SMA X $_{6}$} & $\geq \mathrm{KKM}$ & Tuntas & 20 & 90,91 \\
\hline & $<\mathrm{KKM}$ & Tidak Tuntas & 2 & 9,09 \\
\hline \multirow{2}{*}{ JUMLAH } & $\geq \mathrm{KKM}$ & Tuntas & 151 & 88,82 \\
\hline & $<\mathrm{KKM}$ & Tidak Tuntas & 19 & 11,18 \\
\hline
\end{tabular}

Ketuntasan belajar siswa dari enam kelas eksperimen mencapai 88,82\%, dengan menggunakan kreteria ketuntasan minimum (KKM) dari KD masing-masing satuan pendidikan tempat uji coba produk. Hasil uji coba ini menunjukkan bahwa produk e-learning dengan schoology yang dikembangkan dapat dinyatakan efektif digunakan sebagai suplemen pembelajaran fisika.

\section{Pembahasan}

Produk e-learning dengan schoology yang dikembangkan mendapatkan penilaian yang baik oleh siswa sebagai pengguna produk. Produk dinilai menarik, mudah digunakan, dan sangat bermanfaat bagi siswa dalam pembelajaran fisika. Nilai kemenarikan produk mencapai skor 3,25 berkategori menarik. Penilaian produk dinilai oleh pengguna dari aspek tampilan dan isi $e$ learning yaitu kemenarikan variasi penggunaan huruf, ilustrasi, desain lay-out, 
variasi penggunaan warna, penggunaan gambar-gambar, penggunaan video, soal latihan, kesesuaian permasalahan dalam forum diskusi online. E-learning dilengkapi dengan video dan simulasi pembelajaran yang bertujuan supaya siswa lebih memahami konsep fisika dalam kehidupan sehari-hari dan pada produk e-learning terdapat soal latihan yang dapat diakses oleh siswa untuk melatih pengetahuan, dimana terdapat umpan balik (feedback) yang langsung diketahui oleh siswa setelah selesai megerjakan soal tersebut.

E-learning juga terdapat forum diskusi yang melatih siswa untuk menyampaiakan pendapat atau komentar serta berbagi informasi untuk menyelesaiakan pertanyaan atau diskusi masalah sehingga e-learning. Produk juga dinilai mudah digunakan dalampembelajaran dengan skor 3,24, penilaian pada aspek kemudahan e-learning terdapat beberapa indikator yaitu kejelasan isi e-learning, petunjuk atau panduan penggunaan e-learning, penyajian dan pertanyaan-pertanyaan yang ada dalam $e$ learning. E-learning yang telah dikembangkan meimiliki kejelasan isi, petunjuk atau panduan penggunaan $e$ learning, penyajian dan pertanyaanpertanyaan yang mudah digunakan secara mandiri oleh siswa.

Sedangkan tingkat kebermanfaatan produk mencapai skor 3,31 (sangat bermanfaat), pada produk e-Learning terdapat beberapa indikator yaitu kemanfaatan handout, video dan animasi, soal diskusi, soal latihan soal uji kompetensi atau e-Learning secara keseluruhan. E-Learning juga bermanfaat untuk menambah sumber belajar siswa agar siswa tidak hanya memiliki acuan dari buku saja namun dari materi, animasi, video dan soal yang terdapat pada e-Learning ini. ELearning yang telah dikembangkan terdapat animasi dan video pembelajaran beserta diskusi yang bermanfaat bagi siswa untuk lebih termotivasi sehingga siswa akan memperhatikan pelajaran. Hasil yang relatif sama juga diperoleh pada produk pengembangan e-learning yang dilakukan oleh Hasanah, dkk. (2016) bahwa e-Learning dengan Schoology sebagai suplemen pembelajaran fisika menarik untuk digunakan.

Penggunaan produk e-learning yang dikembangkan dalam pembelajaran fisika di sekolah, produk teruji efektif meningkatkan ketuntasan belajar siswa. Ketuntasan belajar siswa yang dianalisis dalam penelitian ini hanya pada hasil belajar siswa pada ranah kognitif terhadap keriteria ketuntasan belajar (KKM) pada masing-masing KD yang dibelajarkan. Hasil uji menunjukkan bahwa keefektifan produk digunakan dalam pembelajaran fisika mencapai $88,82 \%$ siswa yang tuntas belajar. Seperti terlihat pada Gambar 4.

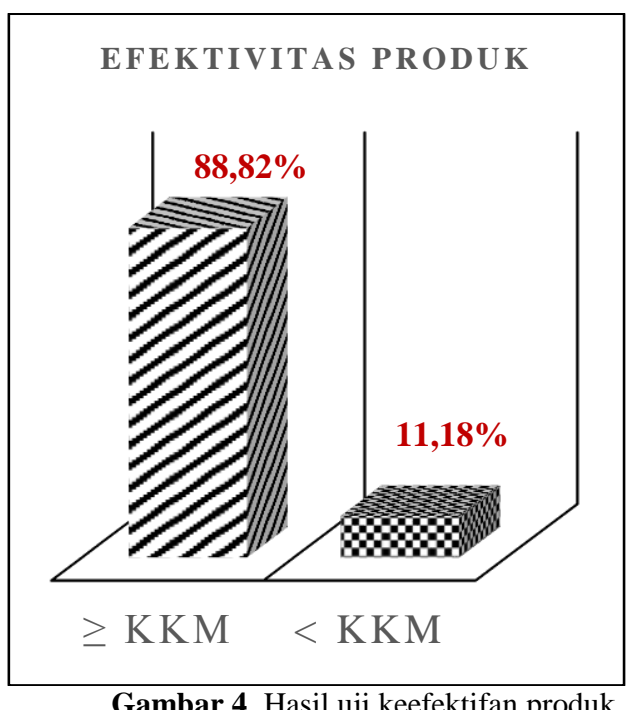

Terlihat pada Gambar 4, siswa yang mencapai ketuntasan belajar mencapai $88,82 \%$, ini termasuk pada pencapaian yang baik. Pencapaian ketuntasan tersebut didapatkan karena pembelajaran didukung oleh keunggulan-keunggulan produk yang dikembangkan diantaranya tampilan menu pada suplemen pembelajaran dalam bentuk E-Learning ini disusun secara sistematis mengikuti format LMS Schoology sehingga memudahkan pengguna dalam mengakses mater pembelajaran yang terdapat di dalam suplemen pembelajaran; suplemen pembelajaran ini di-publish secara online 
sehingga dapat langsung diakses kapan pun dan di mana pun pada komputer atau laptop serta smartphone manapun yang terkoneksi internet dan memiliki aplikasi web browser (seperti Opera, Mozila Firefox, Google Chrome, dan lain-lain); suplemen pembelajaran dalam bentuk $e$ Learning dikembangkan menggunakan LMS Schoology yang tampilannya mirip seperti jejaring sosial, sehingga memudahkan pengguna dalam mengakses konten-kontennya; Produk hasil pengembangan dapat digunakan sebagai suplemen pembelajaran bagi siswa, baik secara mandiri ataupun berkelompok; selain kelebihan yang telah disebutkan, terdapat pula kelebihan lain Schoology jika dibandingkan dengan LMS lain, yaitu ketersediaan convert file gradebook yang berekstensi $c s v$ ke $x l s$.

Kemanarikan program pembelajaran $e$ learning dengan schoology, mampu

membuat siswa antusias dalam melibatkan dirinya melakukan kegiatan pembelajaran, sehingga kondisi ini menjadikan pengetahuan yang mereka dapatkan dari pengalaman pembelajaran tersebut tersimpan dalam memori yang panjang (long term memory). Terbukti bahwa produk e-learning yang dikembangkan efektif mengantarkan siswa dalam mencapai kompetensi.Pembelajaran menggunakan e-learning dengan schoology memberikan pengalaman pembelajaran melalui video, animasi, atau demonstrasi secara virtual. Sehingga siswa dapat merasakan mendapatkan pengalaman belajar langsung dan menarik, walaupun secara virtual. Selain dapat mengembangkan keterampilan proses sebagai pengalaman pembelajaran, melalui pengalamanpengalaman langsung seseorang juga dapat lebih menghayati proses atau kegiatan yang sedang dikerjakan. Hal ini sejalan dengan Edgar Dale dalam Sadiman (2008: 8) yang mengklasifikasi pengalaman menurut tingkat dari yang paling konkret ke yang paling abstrak yang dikenal sebagai kerucut pengalaman (cone of experience), bahwa pembelajaran yang hanya melibatkan secara verbal menghasilkan ingatan hanya $10 \%$ s.d $20 \%$, secara visual (gambar, video dan demonstrasi) hasilnya berkisar $30 \%$, dengan melibatkan siswa mampu berhasil $70 \%$, dan dengan memberikan pengalaman melakukan secara langsung mampu berhasil $90 \%$.

\section{SIMPULAN DAN SARAN Simpulan}

Simpulan yang didapatkan dari penelitian meliputi: (1) program pembelajaran fisika SMA berbasiseLearning dengan Schoology sebagai suplemen pembelajaran tervalidasi, layak dan efektif digunakan untuk pembelajaran;(2) program pembelajaran Fisika berbasisE-Learning dengan Schoology sebagai suplemen teruji menarik, mudah digunakan dan sangat bermanfaat; (3) Program pembelajaran Fisika berbasis E-Learning dengan Schoology sebagai suplemen, efektif digunakan dalam pembelajaran dengan tingkat ketuntasan belajar mencapai $88,82 \%$.

\section{Saran}

Berdasarkan temuan penelitian, dapat dikembangkan e-learning dengan schoology lanjutan untuk pembelajaran virtual class secara berkelompok dari beberapa guru atau sekolah, misal seperti virtual class yang bersifat open class, sehingga akan dihasilkan perbaikan mutu pembelajarannya. Pembelajaran fisika yang akan menggunakan e-learning dengan schoology produk penelitian ini, dengan menggunakan komputer atau laptop, sebaiknya menggunakan resolusi layar 1024 x 600 pixel atau $1280 \times 768$ pixel, agar tampilan yang terdapat pada Schoology akan terlihat jelas dan nampak seluruhnya.

\section{DAFTAR PUSTAKA}

Asyhari, A. (2015). Profil Peningkatan Kemampuan Literasi Sains Siswa Melalui Pembelajaran Saintifik. 
Jurnal Ilmiah Pendidikan Fisika AlBiruni, $\quad 4(2), \quad 179$. https://doi.org/10.24042/jpifalbiruni. v4i2.91

Asyhari, A., \& Diani, R. (2017). Pembelajaran Fisika Berbasis Web Enhanced Course: Mengembangkan Web-logs Pembelajaran Fisika Dasar 1. Jurnal Inovasi Teknologi Pendidikan, 4(1), 13-25.

Chidayati, N., Sesunan, F., \& Suana, W. (2017). Pengembangan Suplemen Pembelajaran Fisika pada Materi Gerak Melingkar dengan Schoology. Jurnal Pembelajaran Fisika, 5(1), 121-132.

Darmawan, D. (2014). Pengembangan ELearning Teori dan Desain. Bandung: PT Remaja Rosdakarya.

Fatur. (2013). Schoology jejaring soasial yang sangat bermanfaat bagi guru dan siswa.

Gumrowi, A. (2016). Meningkatkan Hasil Belajar Listrik Dinamik menggunakan Strategi Pembelajaran Team Assisted Individualization melalui Simulasi Crocodile Physics. Jurnal Ilmiah Pendidikan Fisika AlBiruni, 5(1), 105-111. https://doi.org/10.24042/jpifalbiruni. v5i1.110

Hasanah, N., Suyanto, E., \& Wayan Suana. (2016). E-Learning dengan Schoology sebagai Suplemen Pembelajaran Fisika Materi Elastisitas dan Hukum Hooke. Jurnal Pembelajaran Fisika, 4(2), 71-81.

Irwandani. (2016). Potensi media sosial dalam mempopulerkan konten sains islam. Jurnal Keguruan Dan Ilmu Tarbiyah, 1(2), 173-177.

Jayanti, R. D., Romlah, R., \& Saregar, A. (2016). Efektivitas Pembelajaran Fisika Model Problem Based Learning (PBL) melalui Metode POE terhadap Kemampuan Berpikir Tingkat Tinggi Peserta Didik. In Seminar Nasional Pendidikan (pp.
208-214). Bandar Lampung: Program Studi Pendidikan Fisika Universitas Lampung.

Juniarti, R. D., Sarwono, \& Endarto, D. (2014). Pengembangan Media Mobile Learning dengan Aplikasi Schoology pada Pembelajaran Geografi Materi Hidrosfer Kelas X SMA Negeri 1 Karanganyar. GEADIDAKTIKA-Jurnal Pendidikan Geografi, $3(1)$. https://doi.org/10.3975/cagsb.2015.0 5.08

Kemendikbud. (2014). Petunjuk Peningkatan Mutu Pendidikan di Sekolah. Jakarta, Indonesia.

Kurniawan, D. T. (2014). Model Pembelajaran Berbasis Masalah Berbantuan Website Interaktif pada Konsep Fluida Statis untuk Meningkatkan Penguasaan Konsep dan Keterampilan Proses Sains Siswa Kelas XI. Jurnal Pengajaran MIPA, 19(2), 206-213. https://doi.org/http://journal.fpmipa.u pi.edu

Pertiwi, I. C., Sukadi, \& Pursika, I. N. (2014). Penerapan Strategi Pembelajaran E-Learning Untuk Meningkatkan Hasil Belajar Siswa dalam Mata Pelajaran Pendidikan Kewarganegaraan pada Siswa Kelas $X$ Tataniaga B di SMA Negeri 1 Singaraja. Jurnal Jurusan Pendidikan PKn, 2(1).

Purwaningsih, R., Rosidin, U., \& Wahyudi, I. (2014). Pengaruh Penggunaan E-learning dengan Schoology Terhadap Hasil Belajar Peserta Didik, (1), 51-61.

Ramadhani, M. (2012). Efektivitas penggunaan media pembelajaran ELearning berbasis Web pada Pembelajaran Teknologi Informasi dan Komunikasi terhadap Hasil Belajar Siswa Kelas X SMA Negeri 1 Kalasan. Universitas Negeri Yogyakarta.

Rossett, A., Douglis, F., \& Frazee, R. 
(2003). Strategies for building blended learning. Learning Circuits, June, 4-9.

Sadiman. (2008). Media Pendidikan, Pengetian, Pengembangan, dan Pemanfaatannya. PT Raja Grafindo Persada.

Saregar, A., \& Sunarno, W. (2013). Eksperimen dan Demonstrasi Diskusi menggunakan Multimedia Interaktif ditinjau dari Sikap Ilmiah dan Kemampuan Verbal Siswa. Jurnal Inkuiri, 2(2), 100-113.

Setiawan, W., Hana, M. N., \& Waslaluddin. (2014). Analisis Penerapan Sistem E-Learning FPMIPA UPI Menggunakan Technology Acceptance Model (TAM). Jurnal Pengajaran MIPA, 19(1), $128-140$. https://doi.org/http://journal.fpmipa.u pi.edu

Suana, W., Maharta, N., Nyeneng, \& Wahyuni, S. (2017). Design and Implementation Of Schoology-Based Blanded Learning Media For Basic Physics I Course. Jurnal Pendidikan IPA Indonesia, 6(1), 170-178. https://doi.org/10.15294/jpii.v6i1.72
05

Sugiono. (2010). Metode Penelitian Pendidikan. Bandung: Alfabeta.

Sukiman. (2012). Pengembangan Media Pembelajaran. Yogyakarta: Pedagogia.

Wijayanti, W., Maharta, N., \& Suana, W. (2017). Pengembangan Perangkat Blended Learning Berbasis Learning Management System pada Materi Listrik Dinamis. Jurnal Ilmiah Pendidikan Fisika Al-Biruni, 6(1), 1. https://doi.org/10.24042/jpifalbiruni. v6i1.581

Yuberti. (2014). Penelitian Dan Pengembangan" Yang Belum Diminati Dan Perspektifnya. Jurnal Ilmiah Pendidikan Fisika Al-Biruni, 3(2), $1-15$. https://doi.org/http://dx.doi.org/10.24 042/jpifalbiruni.v3i2.69

Yuberti. (2015). Online Group Discussion pada Mata Kuliah Teknologi Pembelajaran Fisika. Jurnal Ilmiah Pendidikan Fisika Al-Biruni, 4(2), 145-153.

https://doi.org/10.24042/jpifalbiruni. v4i2.88 